\title{
ANALISIS FORENSIK DIGITAL PADA FROZEN SOLID STATE DRIVE DENGAN METODE NATIONAL INSTITUTE OF JUSTICE (NIJ)
}

\author{
Imam Riadi ${ }^{1}$, Rusydi Umar ${ }^{2} \&$ Imam Mahfudl Nasrulloh ${ }^{3}$ \\ ${ }^{1,2,3}$ Universitas Ahmad Dahlan Yogyakarta \\ E-mail: mahfudz.mail@gmail.com
}

\begin{abstract}
Computer crime has evidence of digital crime and needs to be analyzed. The rapid development of computer technology has brought changes in the field of hardware. In hardware today there is a Solid State Drive (SSD) as the primary storage of the computer, because the SSD technology has fast data access speed. The use of drive freezing software on computers is often done by computer technicians, as it can save on maintenance costs. This software is used to protect the computer from unwanted changes, computer systems that use frozen drive software are not stored on storage media after the computer is shut down. When this happens, what digital forensic investigators must do. This study discusses the comparison of related forensic tools used for the examination and analysis process. The collection of digital evidence is carried out by static forensic methods, while the research and analysis stage adjusts and implements forensic methods from the National Institute of Justice (NIJ) to obtain digital evidence. Drive freezing software such as Shadow Defender has been shown to influence the practice of digital forensic examination on the acquisition of digital evidence, with a successful file restoration percentage of only $28.7 \%$ so that it can become an obstacle in the digital forensic process.
\end{abstract}

Keywords: Forensic, Digital, Evidence, SSD, NIJ

\begin{abstract}
ABSTRAK
Kejahatan komputer memiliki bukti digital dari tindak kejahatan dan perlu dilakukan analisa. Perkembangan teknologi komputer yang demikian pesat telah membawa perubahan pada bidang perangkat keras. Pada perangkat keras saat ini terdapat Solid State Drive (SSD) sebagai media penyimpanan utama komputer, karena teknologi $S S D$ memiliki kecepatan akses data yang cepat. Penggunaan software pembeku drive pada komputer sering dilakukan oleh teknisi komputer, karena dapat menghemat biaya perawatan. Software tersebut digunakan untuk melindungi komputer dari perubahan yang tidak dikehendaki, sistem komputer yang tanam software tersebut menjadikan perubahan yang terjadi pada sistem komputer tidak disimpan pada media penyimpanan setelah komputer dimatikan. Ketika hal ini terjadi apa yang harus dilakukan oleh penyidik forensik digital. Penelitian ini membahas perbandingan terkait tool Forensik yang digunakan untuk proses eksaminasi dan analisa. Pengambilan salinan bukti digital dilakukan dengan metode forensik statik, sedangkan tahapan penelitian dan analisa mengadaptasi dan mengimplementasikan metode forensik dari National Institute of Justice (NIJ) untuk mendapatkan bukti digital. Software pembeku drive seperti Shadow Defender terbukti berpengaruh terhadap praktik eksaminasi forensik digital terhadap didapatkannya bukti-bukti digital, dengan kondisi tersebut prosentase keberhasilannya merestorasi file hanya $28,7 \%$ sehingga dapat menjadi hambatan dalam proses forensik digital.
\end{abstract}

Kata kunci: Forensik, Bukti, Digital, SSD, NIJ

\section{PENDAHULUAN}

Perkembangan teknologi informasi dan komunikasi yang demikian pesat telah membawa perubahan pada bidang perangkat lunak (software), perangkat keras (hardware), dan budaya masyarakat (brainware). Aktivitas penggunaan teknologi informasi dan komunikasi yang pada mulanya menuntut peralatan-peralatan pemrosesan data yang sangat besar dan rumit, kini digantikan oleh perangkat otomasi digital dan perangkat jinjing (portable). Aktifitas manusia saat ini sebagian besar berhubungan dengan data, informasi, dan komunikasi, serta dalam kegiatannya secara langsung maupun tidak langsung akan berhubungan dengan perangkat teknologi komputer. Penggunaan teknologi komputer sehari-hari pada dasarnya memiliki manfaat 
yang sangat besar, sebagai dampak penggunaan dari komputer memiliki manfaat positif dan ada dampak negatif. Manfaat secara positif dari teknologi komputer yang ditimbulkan sangat bermanfaat, sehingga dapat membantu proses dari pekerjaan yang sulit menjadi mudah dan membantu aktivitas manusia menjadi lebih mudah, cepat, serta efisien. Adapun dampak teknologi komputer secara negatif yaitu adanya penyalahgunaan terhadap teknologi komputer itu sendiri yang digunakan untuk tindak kejahatan, sehingga dapat menimbulkan kerugian perseorangan, golongan, instansi, lembaga, atau bahkan negara.

Kejahatan komputer atau disebut computer crime merupakan kejahatan yang melibatkan teknologi komputer yang ada didalamnya ${ }^{(1)}$. Kejahatan komputer memiliki bukti elektronik dan digital dari tindak kejahatan berupa jejak aktivitas kejahatannya dan perlu dilakukan analisa terhadap bukti digital yang didapatkan dengan ilmu dan metode forensik. Pada bidang teknologi, analisa forensik terhadap barang bukti digital atau elektronik disebut dengan sebutan komputer forensik atau digital forensic ${ }^{(2)}$. Digital forensic itu sendiri merupakan tindakan memperoleh, mengambil, melestarikan, dan menyajikan data sesuai dengan metode dan tool forensik.

Pada suatu kasus kejahatan teknologi komputer yang terjadi pada umumnya akan meninggalkan jejak aktivitas kejahatan. Jejak aktivitas (history) yang terkait dengan tindak kejahatan tersebut dapat dijadikan sebagai barang bukti. Barang bukti kejahatan komputer dapat berupa barang bukti elektronik dan barang bukti digital. Barang bukti elektronik dapat berupa bentuk fisik dari perangkat elektronik tersebut atau dapat berupa media simpan (storage device), sedangkan barang bukti digital dapat berupa file dokumen, file history, atau file log yang berisikan data-data terkait yang dapat dijadikan sebagai informasi pendukung pengambil keputusan. Barang bukti elektronik dan barang bukti digital menjadi hal terpenting dalam suatu kasus kejahatan komputer, karena aktivitas tindak kejahatan komputer yang dilakukan terekam oleh sistem komputer pada media penyimpanan utama (primary storage) perangkat komputer. Bukti digital dapat diketahui dan dilihat pada saat kejahatan dilakukan melalui metode live forensics atau setelah terjadi tindak kejahatan dengan metode static forensics. Analisa bukti digital perlu dilakukan sesuai dengan prosedur penanganan khusus, metode analisa forensik yang tepat, dan dengan mengkomparasikan berbagai tool forensik untuk mendapatkan bukti digital yang baik serta terjaga integritas datanya, sehingga dari bukti digital tersebut diperoleh barang bukti berupa informasi yang valid untuk mendukung putusan hukum suatu perkara tindak kejahatan komputer.

Media penyimpanan komputer pada dasarnya terdiri dari dua jenis media penyimpanan yaitu non-volatile memory (NVM) dan volatile memory. Non-volatile memory memungkinkan data yang tersimpan tidak akan hilang meskipun aliran listrik terputus atau tidak tergantung dengan catu daya listrik ${ }^{(3)}$, seperti Harddisk, Solid State Drive (SSD), Flashdisk, Memory Card, Zip Drive, Optical Drive, dan Nand Flash, sedangkan media penyimpanan Violatile Memory akan kehilangan data ketika aliran listrik terputus atau tidak ada catu daya listrik, seperti pada Random Access Memory (RAM), Dynamic Random-access Memory (DRAM), dan Static Random-access Memory (SRAM). Solid State Drive atau Solid State Disk disingkat $S S D$ adalah perangkat penyimpan data yang menggunakan serangkaian integrated circuit atau IC sebagai memori yang digunakan untuk menyimpan data atau informasi ${ }^{(4)}$.

SSD merupakan salah satu media penyimpanan utama selain Harddisk. Teknologi SSD menggunakan solid state memory berbasis NAND flash atau NOR flash pada penyimpanan datanya. SSD menggunakan teknologi yang hampir mirip seperti $R A M$ (Random Access Memory), data dalam SSD berbasis flash biasanya disimpan dalam sel memori pada chip, terdapat dua macam jenis 
sel memori yang umum digunakan, yaitu jenis Multi Level Cell (MLC) dan Single Level Cell (SLC). Secara fisik yang membedakan SSD dengan harddisk (HDD) adalah pada SSD menggunakan semikonduktor atau integrated circuit (IC), sedangkan pada harddisk menggunakan platter magnetis yang berputar. Meskipun secara teknis bukan sebuah disk tetapi bentuk atau dimensi SSD sama dengan Harddisk, sehingga dapat digunakan pada komputer dan notebook (komputer jinjing). $S S D$ juga menggunakan interface yang sama pada harddisk yaitu Serial Advanced Technology Attachment (SATA) atau Integrated Drive Electronics (IDE). Saat ini SSD berangsur-angsur menggantikan posisi harddisk pada media penyimpanan utama komputer, karena teknologi SSD ini memiliki kecepatan akses data yang sangat tinggi.

Penelitian mengenai media penyimpanan komputer yang dilakukan Albana \& Riadi ${ }^{(5)}$ pada suatu kasus kejahatan komputer dengan sistem operasi proprietary menjadi permasalahan bagi penyidik untuk menemukan file dokumen, history, serta perubahan yang dilakukan oleh pelaku kejahatan ketika drive pada suatu harddisk dibekukan menggunakan aplikasi software Deep Freeze, karena jejak pengguna akan terhapus dari memori dan media penyimpanan secara otomatis setelah komputer itu dihidupkan ulang atau restart. Hal tersebut senada apa yang dikatakan oleh perusahaan pengembang software Deep Freeze pada websitenya deepfreeze.com.au, software untuk membekukan drive dapat mengurangi biaya pemeliharaan komputer sebesar 63\%, sehingga untuk menghemat biaya pemeliharaan perkantoran, instansi, dan warnet di Indonesia mengadopsi perangkat lunak ini ${ }^{(6)}$. Tidak dipungkiri pengelola komputer dan internet publik seperti warung internet (warnet) dan internet cafe menggunakan aplikasi-aplikasi sejenis untuk menekan biaya perawatan dan pemeliharaan. Hal ini bisa menjadikan salah satu faktor mengapa kejahatan komputer di Indonesia pada umumnya pelaku kejahatan komputer (computer crime) dan kejahatan dunia maya (cybercrime) lebih cenderung mengakses komputer dan internet ditempat umum seperti warnet dan internet cafe.

Penggunaan software utility untuk membekukan sistem dan drive pada komputer juga sering dimanfaatkan oleh teknisi atau pranata komputer yang digunakan untuk melindungi komputer dari perubahan yang tidak dikehendaki. Beberapa software pembeku drive yang sering digunakan diantaranya DeepFreeze, Shadow Defender, Windows Steady State, dan Toolwiz Time Freeze. Pada software tersebut memiliki fitur system restore dan pembeku drive pada Harddisk, SSD, dan media simpan utama lainnya. Ketika pengaturan pada software tersebut diaktifkan maka perubahan yang terjadi pada sistem komputer tidak akan disimpan pada media penyimpanan. Sistem kerja software tersebut pada saat komputer dimatikan dan dihidupkan kembali maka keadaan sistem komputer seperti semula sebelum dilakukan perubahan, begitu juga jika melakukan proses penyimpanan file pada drive yang dibekukan, maka ketika komputer dimatikan dan dihidupkan kembali drive akan kembali seperti sebelum dilakukan penyimpanan file. Hal ini menjadikan tantangan investigator forensik komputer (digital forensics) dan bagaimana melakukan analisa bukti-bukti digital pada kondisi tersebut diatas jika terjadi pada media penyimpanan Solid State Disk (SSD) yang dibekukan (frozen)?

Kondisi drive SSD yang dibekukan atau frozen solid state drive (SSD) yang dimaksudkan disini adalah SSD tersebut dilakukan pembekuan drive, dimana sistem komputer tersebut terinstal software utility yang digunakan untuk melindungi komputer dari perubahan yang tidak dikehendaki. Software utility pembeku drive yang digunakan pada penelitian awal ini adalah Shadow Defender. Dikatakan pada website pengembang software Shadow Defender ${ }^{(7)}$ aplikasi tersebut akan mengambil snapshot dari disk dan menjalankan setiap file dalam mode virtual, setelah pengguna keluar dari dimensi 
paralel setiap perubahan pada sistem dan file pada disk akan dihapus. Kesimpulan dari penggunaan software tersebut adalah komputer tidak akan terpengaruh oleh perubahan apapun dan tidak ada file berbahaya yang akan ditulis ke komputer. Pada keadaan dan sistem komputer pada kondisi seperti inilah menjadi tantangan bagi investigator forensik digital sehingga perlu dilakukan analisis forensik bukti digital pada frozen solid state drive (SSD).

Pengumpulan bukti digital pada media penyimpan komputer atau non-volatile memory $(N V M)$ atau non-volatile evidence collection melibatkan pengumpulan bukti dari media simpan komputer seperti MMC Card, Compact Flash, Flash Disk, SD Card, Flash Memory, Harddisk, Solid State Disk, dan yang sejenis ${ }^{(1)}$. Penelitian lainnya terhadap media simpan yang pernah dilakukan, yaitu penelitian terhadap Harddisk dan SSD dengan perlakuan yang sama, file yang sama, dilakukan penghapusan file dan format dengan interval yang sama kemudian dianalisis menggunakan tool FTK Toolkit, diperoleh hasil bahwa setelah dilakukan tindakan yang sama pada kedua drive tersebut hasil yang diperoleh tidak sama sehingga menimbulkan permasalahan bagi penyidik ${ }^{(8)}$. Hasil penelitian serupa pada forensik digital SSD menunjukkan hasil perolehan data pada SSD tidak dapat diprediksi dan bervariasi ${ }^{(4)}$. Hasil perolehan data pada $S S D$ ada pengaruh dari fitur TRIM, TRIM terbukti berpengaruh terhadap praktek examinasi dan analisis forensika digital pada $S S D^{(9)}$. SSD dalam posisi fitur TRIM dalam keadaan non-aktif (disable) sebagian besar data yang terhapus data di-recovery kembali seperti halnya melakukan recovery data pada Harddisk konvensional. Namun, berbeda dengan SSD dalam posisi fitur TRIM dalam keadaan aktif (enable), sebagian besar data yang terhapus tidak dapat di-recovery kembali. TRIM merupakan sebuah perintah yang langsung ditujukan kepada kepada firmware dari SSD.

Selain itu tool forensik yang sesuai diperlukan untuk mengumpulkan bukti dan memastikan diterimanya bukti digital dan integritas dari keaslian bukti digital yang didapatkan dan juga perlu dipastikan melalui mekanisme seperti hashing atau menerapkan write protection untuk menjaga integritas data dan mencegah adanya perubahan data atau file yang mengakibatkan tidak diterimanya sebagai bukti digital. Perbedaan penggunaan tool forensik juga akan mempengaruhi bukti digital yang didapat. Pada penelitian Rosalina et al (10) melakukan analisa forensik menggunakan tool forensik yaitu X-Ways Forensics dan WinHex dari kedua tool tersebut dapat digunakan untuk mekanisme pengembalian data atau file secara otomatis maupun pengembalian secara manual, dan dapat digunakan pada media penyimpanan termasuk SSD. Selain obyek forensik dan tool forensik adalah metode analisa forensik, menurut Argawal ${ }^{(1)}$ pemilihan model, metode, atau sistematika investigasi digital forensik diantaranya harus memenuhi individualitas (individuality), keterulangan (repeatability), kehandalan (reliability), kinerja (performance), kemampuan uji (testability), skalabilitas (scalability), dan standar kualitas (quality standards). Pada analisa forensik dapat mengacu dan menggunakan metode dari National Institute of Justice (NIJ) dengan alur identification, collection, examination, analysis, dan reporting ${ }^{(11)}$, atau dapat menggunakan metode dari National Institute of Standards and Technology (NIST) dengan rangkaian forensik collection, examination, analysis, dan reporting ${ }^{(12)}$.

\section{METODE}

Pada penelitian ini mengadaptasi dan mengimplementasikan metode analisa forensik dari National Institute of Justice (NIJ). Metode ini untuk menjelaskan bagaimana tahapan penelitian yang akan dilakukan sehingga dapat diketahui alur dan langkah-langkah penelitian secara sistematis sehingga dapat dijadikan pedoman dalam menyelesaikan permasalahan yang ada. Menurut Anggara ${ }^{(11)}$ disebutkan melakukan teknik forensik dan analisa 
forensik berdasarkan metode yang benar akan memiliki keberhasilan hampir 100\% dalam mengumpulkan data forensik. Tahapan pada penelitian ini dapat digambarkan seperti pada Gambar 1.

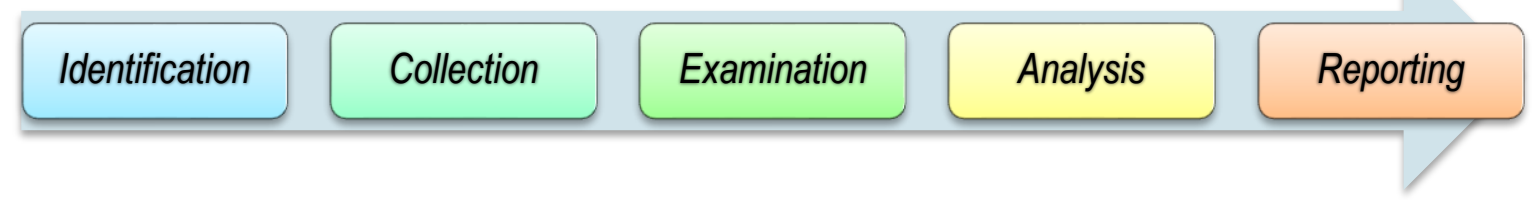

Gambar 1. Metode National Institute of Justice (NIJ)

Tahapan metode dari National Institute of Justice (NIJ) ini terbagi menjadi lima tahapan yakni identification, collection, examination, analysis, dan reporting ${ }^{(11)}$, secara lengkap dipaparkan sebagai berikut:

Tahap identification atau tahap identifikasi merupakan kegiatan pemilahan barang bukti tindak kejahatan digital dan pemilahan data-data untuk mendukung proses penyidikan dalam rangka pencarian barang bukti kejahatan digital. Pada tahap ini didalamnya terdapat proses identifikasi, pelabelan, perekaman, untuk menjaga keutuhan barang bukti.

Tahap collection atau tahap pengumpulan merupakan serangkaian kegiatan mengumpulkan data-data untuk mendukung proses penyidikan dalam rangka pencarian barang bukti kejahatan digital. Pada tahap ini didalamnya terdapat proses pengambilan data dari sumber data yang relevan dan menjaga integritas barang bukti dari perubahan.

Tahap examination atau tahap pemeriksaan ini merupakan tahap pemeriksaan data yang dikumpulkan secara forensik baik secara otomatis atau manual, serta memastikan bahwa data yang didapat berupa file tersebut asli sesuai dengan yang didapat pada tempat kejadian kejahatan komputer, untuk itu pada file digital perlu dilakukan identifikasi dan validasi file dengan teknik hashing.

Tahap analysis atau tahap meneliti ini dilakukan setelah mendapatkan file atau data digital yang diinginkan dari proses pemeriksaan sebelumnya, selanjutnya data tersebut dianalisis secara detail dan komprehensif dengan metode yang dibenarkan secara teknik dan hukum untuk dapat membuktikan data tersebut. Hasil analisis terhadap data digital selanjutnya disebut digunakan sebagai barang bukti digital serta dapat dipertanggungjawabkan secara ilmiah dan secara hukum.

Tahap reporting atau tahap pelaporan dilakukan setelah diperoleh barang bukti digital dari proses pemeriksaan dan dianalisis. Selanjutnya pada tahap ini dilakukan pelaporan hasil analisis yang meliputi penggambaran tindakan yang dilakukan, penjelasan mengenai tool, dan metode yang digunakan, penentuan tindakan pendukung yang dilakukan, dan memberikan rekomendasi untuk perbaikan kebijakan, metode, tool, atau aspek pendukung lainnya pada proses tindakan digital forensik. Adapun tahapan penelitian yang dilalui pada penelitian ini mengacu pada 5 (lima) tahap dari National Institute of Justice (NIJ) dan langkah dari penelitian ini dibagi menjadi 3 (tiga) tahapan utama seperti pada Gambar 2.

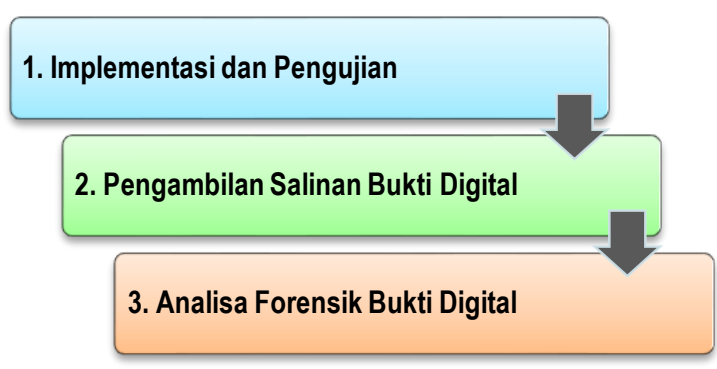

Gambar 2. Tahapan Penelitian

Pada penelitian ini bukti digital yang digunakan tidak didapatkan pada lingkungan yang sebenarnya atau barang bukti tidak didapatkan dari hasil tindak kejahatan komputer yang sebenarnya, melainkan bukti 
digital dibuat dan peroleh dari hasil skenario pada tahap implementasi dan pengujian yang akan dibahas pada bagian sub-bab tersendiri. Tahap implementasi dan pengujian forensik bukti digital pada SSD yang dibekukan (frozen solid state drive) ditunjukkan pada alur Gambar 3.

Implementasi dan pengujian dilakukan dengan desain skenario, dengan tujuan untuk mendapatkan bukti digital seperti pada kasus kejahatan komputer yang sebenarnya. Alur pada tahapan sesuai Gambar 3 merupakan implementasi dan pengujian forensik bukti digital pada frozen solid state drive (SSD). Pada tahap ini dilakukan praktek fungsi frozen (pembekuan) pada drive SSD, yaitu mengaktifkan fitur frozen pada software Shadow Defender. Tampilan software Shadow Defender seperti pada Gambar 4 untuk mengaktifkan pembekuan drive (frozen drive) dengan mengaktifkan Shadow Mode.

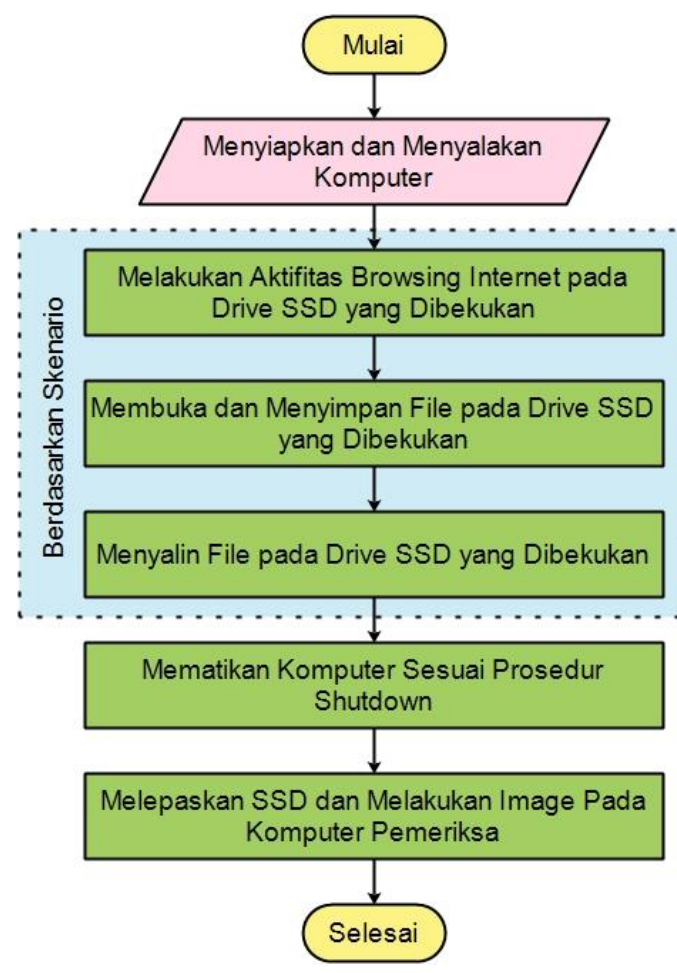

Gambar 3. Tahapan Implementasi dan Pengujian

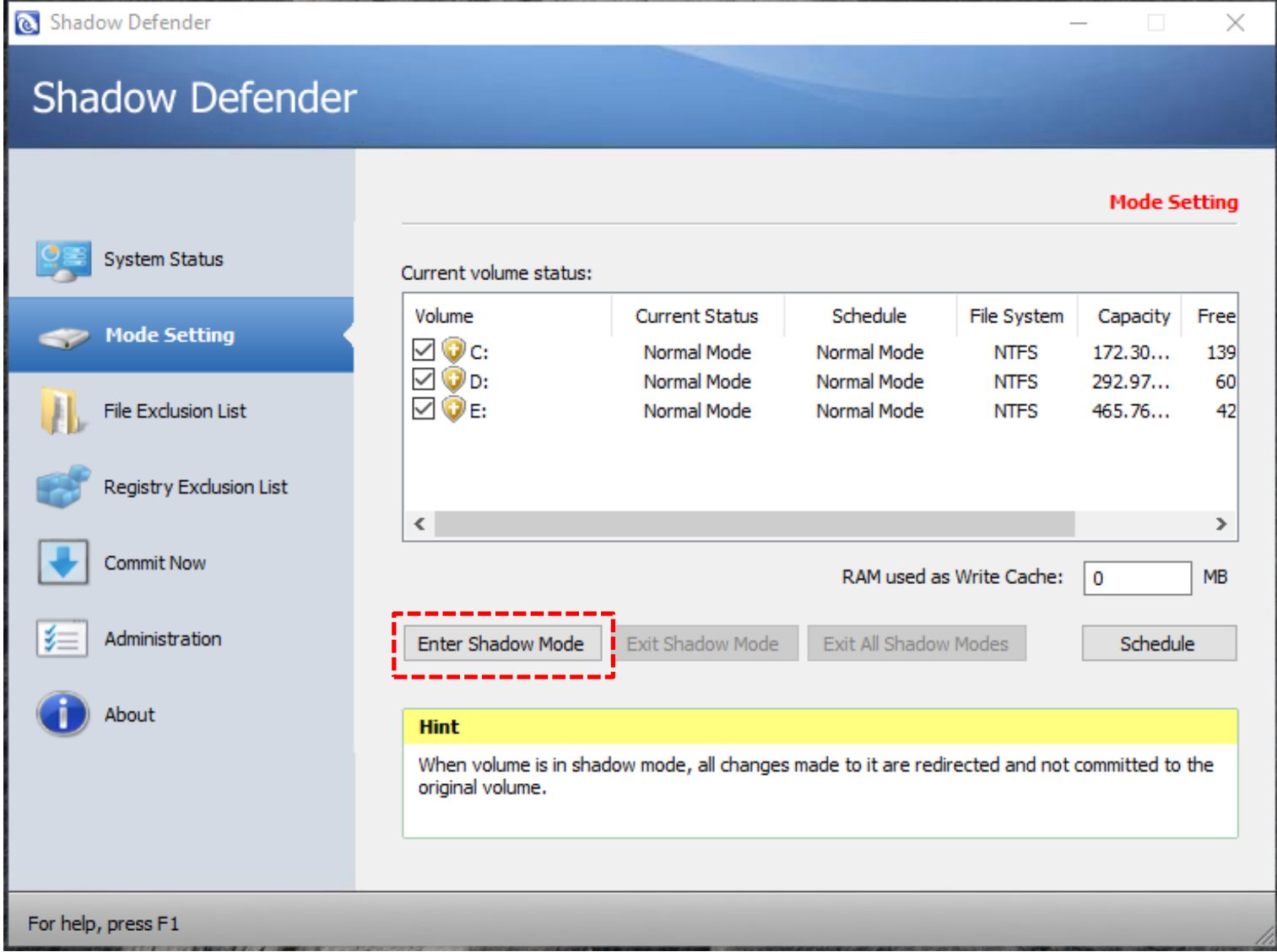

Gambar 4. Tampilan Shadow Defender 
Implementasi yang dilakukan terhadap fungsi frozen (pembekuan) pada drive SSD yaitu melakukan aktifitas menggunakan komputer secara normal dan seolah-olah digunakan untuk tindak kejahatan dengan membuat dan menyalin berbagai macam file dokumen (.doc, .xls, .ppt, .pdf), file gambar (.jpg, .png), file aplikasi (.exe), file multimedia (.mp3, .mp4), dan melakukan aktifitas browsing internet. Setelah dimelakukan sekenario penggunaan komputer seolah-olah digunakan kejahatan tahap berikutnya adalah melakukan akuisisi atau membuat salinan terhadap drive SSD yang dibekukan dengan membuat image drive menggunakan software OSForensics untuk menganalisis file-file apa saja yang dapat dikembalikan atau direstorasi setelah komputer dimatikan dalam kondisi drive dibekukan (frozen drive) pada SSD. Tools yang digunakan dalam praktek analisis adalah OSForensics, Autopsy dan WinHex guna kebutuhan analisis serta FTK Imager guna membuat image dari SSD.

Pengambilan bukti digital mengacu pada metode static forensic atau disebut juga metode akuisisi secara tradisional, hal ini berfokus pada memeriksa salinan duplikat ${ }^{(14)}$. Pengambilan salinan bukti digital harus tetap dipastikan konsisten dengan aslinya, sehingga hasil yang didapat pada kondisi baik ${ }^{(15)}$. Pada umumnya ketika menjalankan tool forensik baik dalam analisis metode static atau live untuk memperoleh data, proses tersebut dapat menimpa struktur data dari data sebelumnya yang dapat menyebabkan inkonsistensi data. Tahapan pengambilan salinan pada penelitian ini menerapkan metode statis yaitu pengambilan bukti digital dilakukan pada komputer dalam keadaan mati (off), alur pengambilan salinan bukti digital seperti pada Gambar 5.

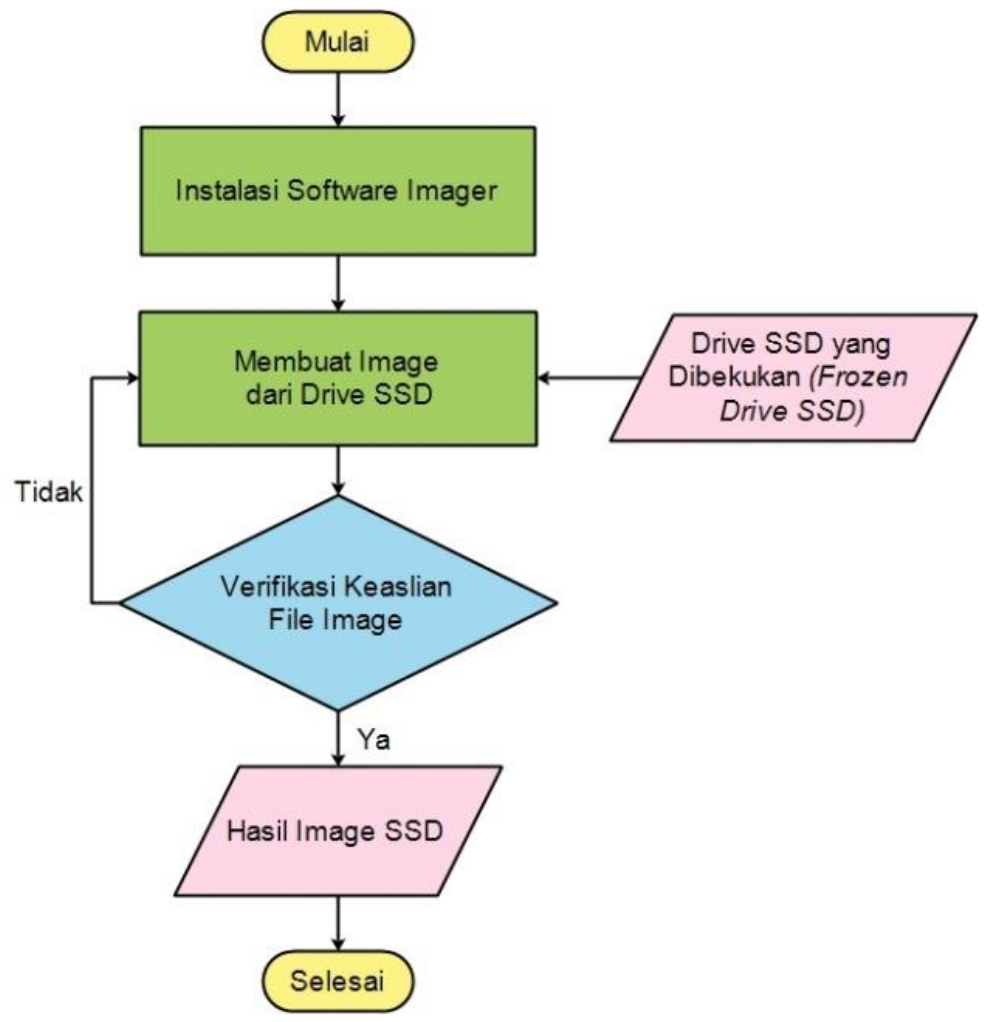

Gambar 5. Tahapan Pengambilan Salinan

Tahapan diatas dilalui agar bukti salinan berupa image drive memiliki kesamaan dengan drive aslinya, dan memiliki struktur data dan file yang sama. Pada tahapan analisa forensik bukti digital pada SSD yang dibekukan (frozen solid state drive) secara garis besar mengimplementasikan metode forensik dari National Institute of Justice 
(NIJ). Hasil salinan atau image dilakukan duplikasi dan dianalisa menggunakan tool software OSForensics, Autopsy, dan Winhex untuk menemukan bukti digital. Bukti digital yang diharapkan ditemukan adalah file dokumen (.doc, .xls, .ppt, .pdf), file gambar (.jpg, .png), file aplikasi (.exe), file multimedia (.mp3, .mp4) history internet, dan catatan terbaru penggunaan komputer. Tahapan analisis forensik digambarkan pada Gambar 6.

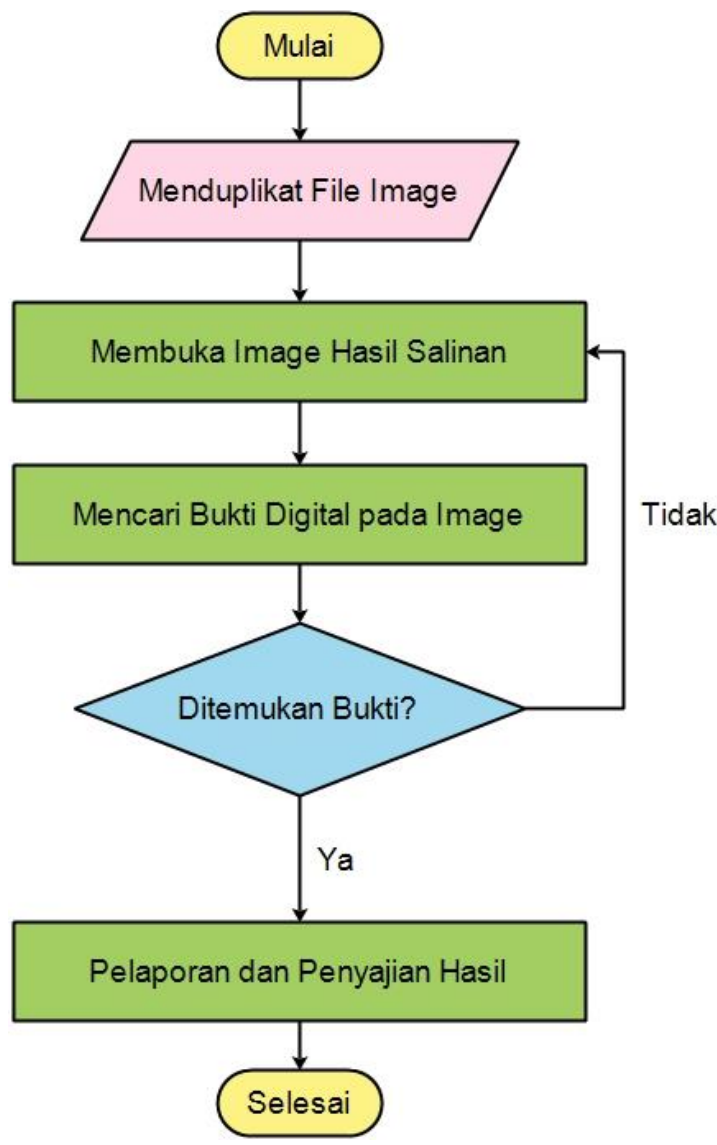

Gambar 6. Tahapan Analisa Forensik

Melalui tahapan analisa forensik yang dilalui diperoleh bukti-bukti digital file-file yang terkait dengan kejahatan tersebut, kemudian disajikan dalam bentuk laporan hasil. Sehingga laporan dari analisa tersebut dapat mendukung informasi berupa siapa, kapan, dan dimana kejahatan komputer tersebut dilakukan, yang kemudian dilanjutkan dengan proses hukum sesuai dengan prosedur yang ada.

\section{HASIL DAN PEMBAHASAN}

Hasil pada tahap implementasi dan pengujian yang dilakukan sesuai desain skenario, dengan tujuan untuk mendapatkan bukti digital seperti pada kasus kejahatan komputer yang sebenarnya maka dibuat skenario: Melakukan aktifitas internet membuka laman web dan mengunduh beberapa file .doc, .pdf, dan .mp3,Membuka, melakukan pengeditan, dan menyimpan file pada drive SSD yang dibekukan dengan software utility pembeku drive Shadow Defender, file yang digunakan pengujian, Menyalin file pada drive SSD yang dibekukan melalui flashdisk dan begitu juga sealiknya, Guna membuktikan validitas file yang dibuat terhadap hasil analisa forensik dan recovery file maka dilakukan hashing pada setiap file yang dibuat dan disalin pada drive SSD yang dibekukan seperti pada Gambar 7.
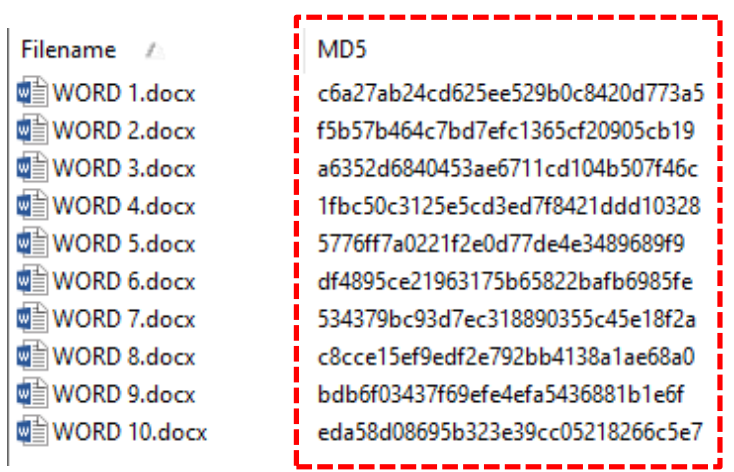

Gambar 7. Nilai Hashing pada File

Kemudian mematikan komputer seolah-olah komputer tersebut telah dipakai, dan langkah selanjutnya melakukan pembuatan salinan pada komputer pemeriksa.

Hasil dari tahap implementasi dan pengujian yang dilakukan sesuai desain skenario selanjutnya dilakukan akuisisi atau membuat salinan drive solid state drive ( $S S D)$, yaitu dengan membuat image menggunakan tool forensik FTK Imager atau OSForensic. Hal ini dimaksudkan barang bukti yang diperoleh yaitu solid state drive (SSD) tidak 
rusak dan tidak berubah baik struktur direktori, struktur file, dan struktur datanya ketika dilakukan proses eksaminasi dan analisa forensik, karena jika data atau file tersebut berubah maka dianggap ada perubahan barang bukti. Barang bukti tersebut setelah dibuat salinan akan disimpan dan dibuka kembali pada saat dipengadilan jika diperlukan.

Hasil imaging dari drive SSD Samsung 850 Evo 120GB menunjukan 2 partisi, partisi pertama memiliki ukuran 77565263872 bytes dan partisi kedua memiliki ukuran 41941991424 bytes. Setelah dibuat file salinan berupa image drive untuk memastikan hasil salinan dan integritas salinan barang bukti digital maka dilakukan hashing dan mengkomparasikan dengan nilai hash (checksum) yang dimiliki oleh file aslinya seperti pada Gambar 8 dan Gambar 9 memiliki kesamaan nilai hash (checksum).

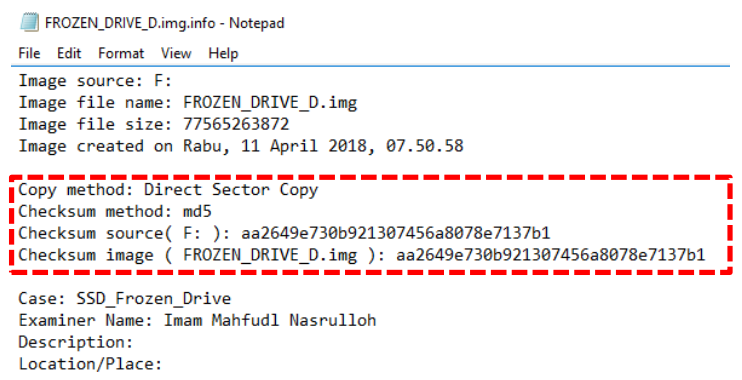

Gambar 8. Nilai Hash Hasil Image

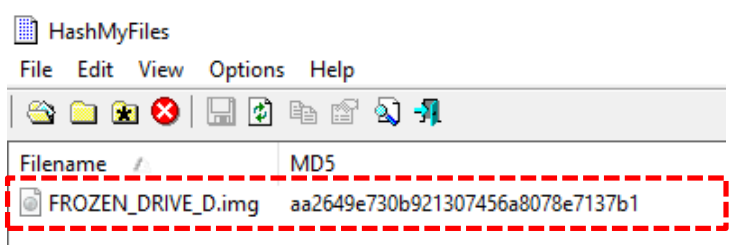

Gambar 9. Nilai Hash Salinan Image

Setelah melakukan pengecekan keotentikan kedua file baik image asli dan image salinan maka tahapan selanjutnya adalah melakukan examinasi dan analisis data pada hasil salinan drive.untuk mendapatkan bukti-bukti atau bukti digital terkait dengan kejahatan digital. Pada bagian ini menjelaskan hasil dari penelitian terhadap analisa forensik bukti digital pada frozen solid state drive $(S S D)$. Setelah pengimplementasian fitur frozen pada SSD dan membuat salinan drive dari aslinya selanjutnya dilakukan analisa forensik. Pada tahap ini tool yang digunakan untuk menganalisa yaitu OSForensics, Autopsy dan WinHex. Secara prinsip dari ketiga tool tersebut sama digunakan untuk membuka struktur direktori dan struktur data yang ada pada image salinan.

Hasil eksaminasi pada drive SSD yang dibekukan (frozen drive), file yang telah terhapus oleh software Shadow Defender secara otomatis ketika komputer dimatikan dan file yang dihapus secara manual oleh pengguna hasil eksaminasi dan analisa dengan OSForensics versi 3.3 menunjukan struktur direktori dapat dilihat, namun hanya dapat dilihat catatan terakhir komputer saat digunakan (recent activity), sedangkan file-file dan data yang terkait pada tahap skenario dan implementasi pengujian tidak ada, sehingga terkait dengan file yang dibuat pada tahap awal tidak dapat dapat direstorasi, tampilan hasil analisa dengan menggunakan OSForensics seperti yang ditunjukkan pada kotak bergaris Gambar 10 dibawah ini.

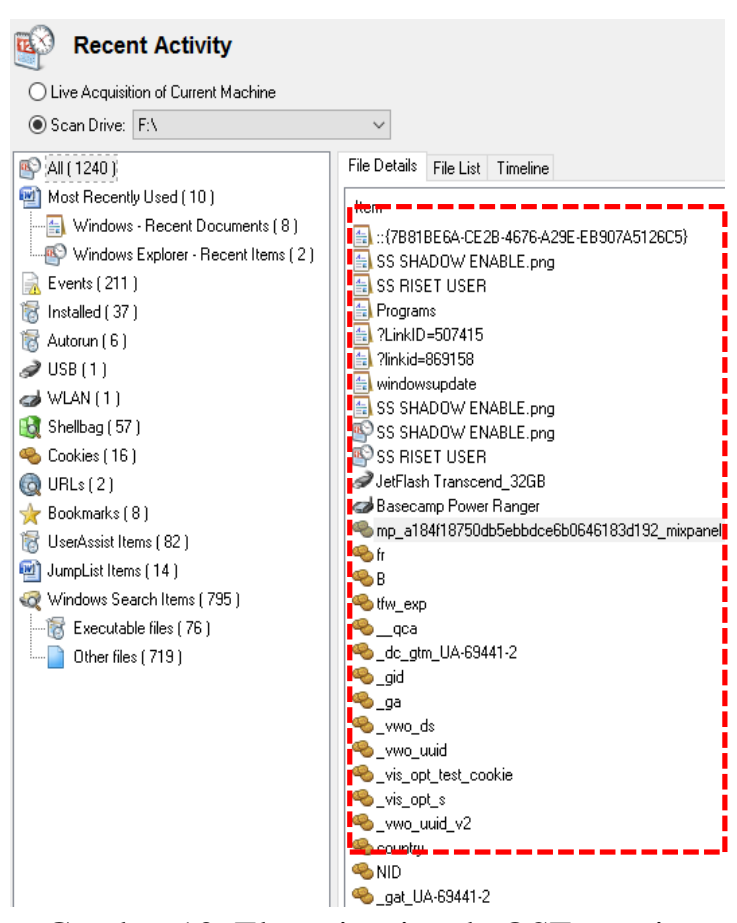

Gambar 10. Eksaminasi pada OSForensics 


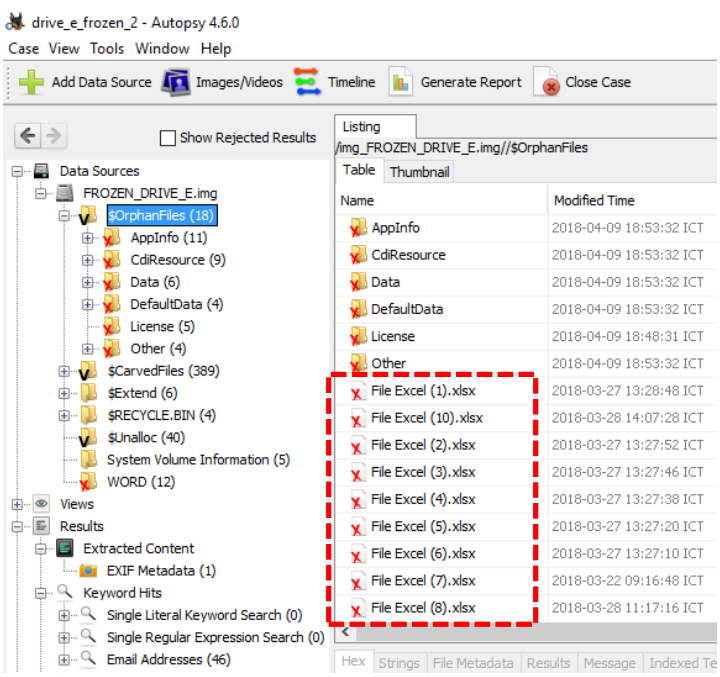

Gambar 11. Eksaminasi pada Autopsy

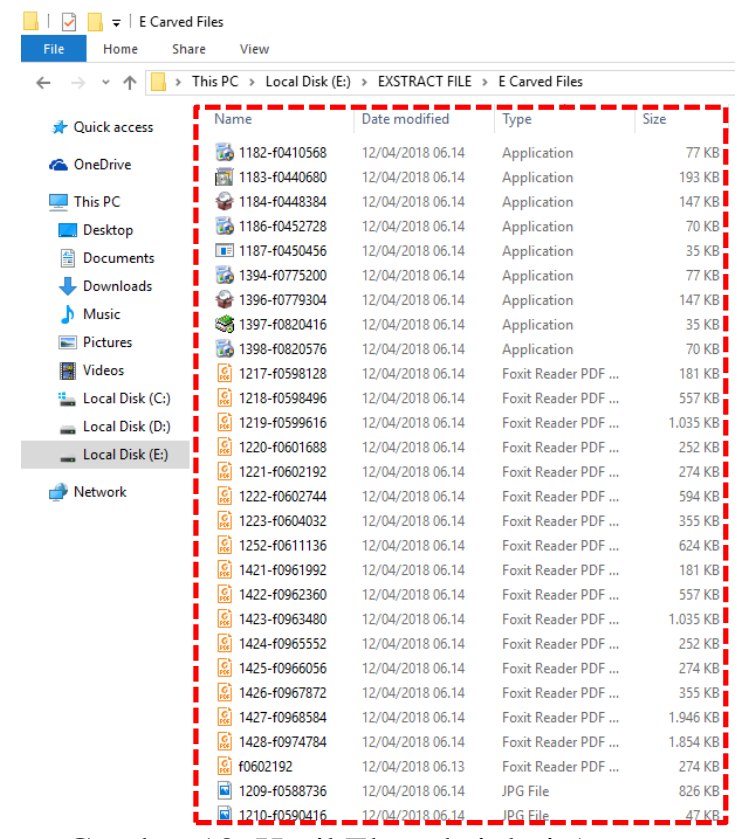

Gambar 12. Hasil Ekstraksi dari Autopsy

Guna membandingkan hasil yang didapat saat analisa maka dilakukan eksaminasi dan pengamatan dengan tool forensik yang kedua, yaitu dengan Autopsy versi 4.6.0. Pada file yang telah terhapus oleh software Shadow Defender secara otomatis ketika komputer dimatikan dan file yang dihapus secara manual oleh pengguna hasil eksaminasi dan pengamatan dengan Autopsy mendapatkan hasil dan file dapat diketemukan, namun file tidak berada pada direktori aslinya melainkan ada pada direktori \$OrphanFiles, \$CarvedFiles, dan \$Unalloc, serta hasil eksaminasi sebagian dapat direstorasi dan dikem'balikan meskipun nama file tidak sama dengan aslinya kondisi file dapat dibuka dengan baik tidak ada kerusakan pada struktur data. Informasi yang menunjukkan catatan terakhir pengguna (recent activity) dapat ditampilkan. Hasil eksaminasi dari Autopsy ditunjukkan pada kotak bergaris Gambar 11 dan hasil ekstraksi seperti pada Gambar 12.

Dari kedua tool forensik, OSForensics dan Autopsy belum dapat menampilkan sejarah internet (history internet) maka dilakukan took ketiga untuk eksaminasi dan analisa menggunakan WinHex versi 19.6. Hasil yang didapat menggunakan WinHex, catatan sejarah internet (history internet) dapat diketemukan, ditunjukan pada Gambar 13.

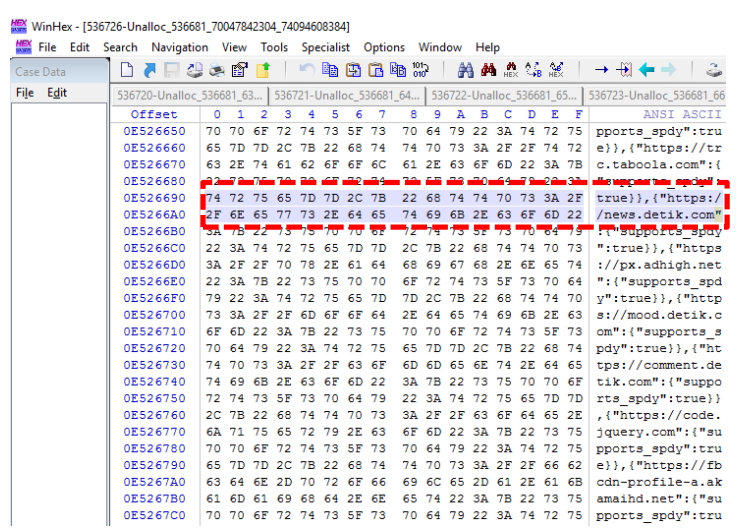

Gambar 13. Eksaminasi pada WinHex

Pada hasil analisa menggunakan WinHex sejarah internet (history) dapat dilihat. Alamat website yang terlihat diduga masih dalam catatn baru (recent activity). Data tersebut tercatat pada direktori \$Unalloc dengan ekstensi file tidak dikenali namun dengan tool WinHex dapat dibaca dan ditampilkan dalam data Hexadesimal atau sistem bilangan basis 16 . Website yang tercatat pada file tersebut diantaranya: https://youtube.com, https://kompas. com, https://news.detik.com, hal ini menunjukan bahwa dengan tool WinHex dapat mengambil informasi sejarah internet (history internet).

Dari hasil eksaminasi dan analisis ketiga tool forensik yang digunakan pada frozen solid state drive (SSD), file yang telah terhapus oleh software Shadow Defender secara otomatis ketika komputer dimatikan dan file yang 
dihapus secara manual oleh pengguna sebagian dapat restorasi kembali. Berikut

secara rinci ekstensi file yang dapat direstorasi seperti pada Tabel 1 .

Tabel 1. Daftar File yang Dapat Direstorasi Pada Kondisi Drive Dibekukan

\begin{tabular}{lccc}
\hline \multicolumn{1}{c}{ Jenis File } & \multicolumn{2}{c}{ Tool Software } & Winhex \\
\hline File Dokumen & OSForensics & Autopsy & Tidak \\
.doc & Tidak & Ya & Tidak \\
.xls & Tidak & Ya & Tidak \\
.ppt & Tidak & Sebagian & Tidak \\
.pdf & Tidak & Sebagian & \\
File Gambar & Tidak & Sebagian & Sebagian \\
.jpg & Tidak & Sebagian & Sebagian \\
.png & Tidak & Sebagian & Tidak \\
File Multimedia & Tidak & Sebagian & Tidak \\
.mp3 & & & \\
.mp4 & Tidak & Sebagian & Tidak \\
File Aplikasi & & & \\
.exe & Tidak & Tidak & Sebagian \\
File Log & Ya & Ya & Tidak \\
History Internet & & & \\
Catatan terakhir & & &
\end{tabular}

Dari hasil eksaminasi dan analisa forensik didapatkan informasi berupa file dan informasi pendukung lainnya. File yang didapat dapat direstorasi, namun untuk melihat keaslian dari file tersebut maka dilakukan teknik hashing, diasumsikan bahwa jika dari kedua file, baik file asli dan file hasil restorasi memiliki nilai hash yang sama dapat dikatakan file tersebut identik dan sama. Pada Tabel 2 secara detail dapat dijelaskan.

Tabel 2. Hasil Verifikasi dan Validasi Keaslian File dengan Hashing

\begin{tabular}{|c|c|c|c|}
\hline Nama File Asli & Nilai Hashing MD5 File Asli & $\begin{array}{c}\text { Nama File Hasil } \\
\text { Restorasi }\end{array}$ & Nilai Hashing MD5 File Restorasi \\
\hline WORD 1.docx & c6a27ab24cd625ee529b0c8420d773a5 & 1443-f1130576.docx & \\
\hline WORD 2.docx & 57b464c7bd7efc1365cf20905cb19 & 1133456.docx & b57b464c7bd7efc1365cf20905cb19 \\
\hline WORD 3.docx & 352d6840453ae6711cd104b507f46c & 1449-f1133480.docx & a6352d6840453ae6711cd104b507f46c \\
\hline WORD 4.docx & 1fbc50c3125e5cd3ed7f8421ddd 10328 & 1451-f1133504.docx & $1 \mathrm{fbc} 50 \mathrm{c} 3125 \mathrm{e} 5 \mathrm{~cd} 3 \mathrm{ed} 7 \mathrm{f} 8421 \mathrm{ddd} 10328$ \\
\hline WORD 5.docx & 5776ff7a0221f2e0d77de4e3489689f9 & 1453-f1133704.docx & 5776ff7a0221f2e0d77de4e3489689f9 \\
\hline WORD 6.docx & df4895ce21963175b658 & 792.docx & df4895ce219 \\
\hline WORD 7.docx & $534379 \mathrm{bc} 93 \mathrm{~d} 7 \mathrm{ec} 318890355 \mathrm{c} 45 \mathrm{e} 18 \mathrm{f} 2 \mathrm{a}$ & 0493896.docx & $355 \mathrm{c} 45 \mathrm{e} 18 \mathrm{f} 2 \mathrm{a}$ \\
\hline WORD 8.docx & c8cce15ef9edf2e792bb4138a1ae68a0 & $1133824 . \operatorname{doc} x$ & e792bb4138a1ae68a0 \\
\hline WORD 9.docx & bdb6f03437f69efe4efa5436881b1e6f & 1459-f1133856.docx & bdb6f03437f69efe4efa5436881b1e6f \\
\hline WORD 10.docx & eda58d08695b323e39cc05218266c5e7 & 1445-f1130600.docx & eda58d08695b323e39cc05218266c5e7 \\
\hline File Excel (10).xlsx & 71c6f8181fcb01ea752fc8ffcb11a5b6 & 1201-f0575840.xlsx & 71c6f8181fcb01ea752fc8ffcb11a5b6 \\
\hline File Excel (6).xlsx & $31514 f 08 b 4 c c f 357 f c 0 c 1 c 855060 a 03 f$ & 1202-f0581472.xlsx & $31514 \mathrm{f} 08 \mathrm{~b} 4 \mathrm{ccf} 357 \mathrm{fc} 0 \mathrm{c} 1 \mathrm{c} 855060 \mathrm{a} 03 \mathrm{f}$ \\
\hline $\begin{array}{l}\text { KEAMANAN } \\
\text { JARINGAN.ppt } \\
\end{array}$ & ceb6417758b290b1b894573164072fd8 & 1258-f0620072.pptx & ceb6417758b290b1b894573164072fd8 \\
\hline File PDF (1).pdf & 4d1518c91c53da625ae800cfdd06ff90 & 1421-f0961992.pdf & 4d1518c91c53da625ae800cfdd06ff90 \\
\hline File PDF (3).pdf & 603469708cd301 eeea39fe67c31e3497 & f0601688.pdf & 603469708cd301eeea39fe67c31e3497 \\
\hline File PDF (4).pdf & 255d57ee06444c64c43962f6b9103b64 & 1221-f0602192.pdf & 255d57ee06444c64c43962f6b9103b64 \\
\hline File PDF (5).pdf & 144422c1d272faa42c141d9b46617c78 & 1222-f0602744.pdf & 144422c1d272faa42c141d9b46617c78 \\
\hline File PDF (6).pdf & $9 c 4 f c 8 c 6 a 25 f d 9 c 301 e c 07 f f 62 a c e 8 e 0$ & 1223-f0604032.pdf & $9 c 4 f c 8 c 6 a 25 f d 9 c 301$ ec07ff62ace8e0 \\
\hline File PDF (7).pdf & eaec6c18efcef9bc57abee93159475de & 1427-f0968584.pdf & eaec6c18efcef9bc57abee93159475de \\
\hline File PDF (9).pdf & 6b81c90596254a134bad89e9ebe30adb & 1252-f0611136.pdf & 6b81c90596254a134bad89e9ebe30adb \\
\hline File PDF (10).pdf & b4791406338db847ae817c5e1bf3e58e & 1218-f0598496.pdf & b4791406338db847ae817c5e1bf3e58e \\
\hline 01GAC Suara.mp3 & 82ed964902bfb852677397d338bb551e & 1188-f0468488.mp3 & 82ed964902bfb852677397d338bb551e \\
\hline Sheila On 7.mp3 & & & \\
\hline 01 Virgoun Bukti.mp3 & 3db73258697a62f5b53b66086018f014 & 1195-f0508952.mp3 & 3db73258697a62f5b53b66086018f014 \\
\hline Vigroun.mp4 & 93b42b0d7a8dccc435ba75118e8393e7 & 1441-f1102808.mp4 & 93b42b0d7a8dccc435ba75118e8393e7 \\
\hline
\end{tabular}


Berdasarkan informasi yang didapatkan baik dari pengamatan, eksperimen dan beberapa literatur ujukan yang diimplementasikan pada penelitian ini, membuktikan bahwa mekanisme frozen solid state drive ( $S S D)$ atau pembekuan terhadap drive pada SSD dapat menghambat penyelidikan forensik digital. Ketika diaktifkan efek dari mekanisme software pembeku drive memiliki pengaruh pada sitem operasi yang sedang berjalan dan pada drive penyimpanan.

\section{SIMPULAN}

Berdasarkan hasil dari penelitian yang telah dilakukan pada implementasi salah satu software pembeku drive yaitu Shadow Defender yang dapat membekukan suatu drive SSD (frozen solid state drive) dan terbukti berpengaruh terhadap praktik eksaminasi dan analisa forensik terhadap didapatkannya buktibukti digital. Tidak semua file dapat direstorasi dengan baik karena struktur file dan data sudah rusak, serta catatan pengguna komputer (recent activity) dan sejarah internet (history internet) tercatat ketika fitur pembeku drive diaktifkan. Jika dilakukan perhitungan tingkat prosentase keberhasilannya hanya memiliki nilai $28,7 \%$ yang diperoleh dari 85 file yang disiapkan untuk implementasi dan pengujian dan hasil file dari eksaminasi dan yang berhasil direstorasi hanya 25 file. Sehingga dapat menjadi hambatan dalam proses forensik digital (digital forensik) oleh penyidik dan hasil dari penyidikan masih sangat sedikit informasi yang didapatkan dari barang bukti digital.

\section{REFERENSI}

[1] Agarwal, Ankit, Gupta, Megha and Gupta, Saurabh. Systematic Digital Forensic Investigation Model. 2011, International Journal of Computer Science and Security (IJCSS), 5(1), 118131.
[2] Ridho, Faizin, Yudhana, Anton and Riadi, Imam. Analisis Forensik Router Untuk Mendeteksi Serangan Distributed Danial of Service (DDoS) Secara Real Time. 2016. Prosiding Annual Research Seminar 2016. 2(1), 111-116. ISBN: 979587-626-0.

[3] Silberschatz, Abraham, Galvin, Peter Baer and Gagne, Greg. Operating Systeme Concepts: Ninth Edition. United States of America: 2013.

[4] Geier, Florian. The Differences Between SSD And HDD Technology Regarding Forensic Investigations. Computer Science. Degree of Computer Science. Linnaeus University. Swedia. 2015.

[5] Forensic Analysis of Frozen Hard Drive Using Static Forensics Method. Albanna, Faiz and Riadi, Imam. 2017, International Journal of Computer Science and Information Security (IJCSIS), 15(1), 173-178.

[6] Deepfreeze. How Deep Freeze Works (Online). [Cited: November 23, 2017.] http://deepfreeze.com.au/.

[7] Shadowdefender. What is Shadow Defender? (Online).[Cited:November 25, 2017] http://www.shadowdefender.com/.

[8] Marupudi, Shiva Sai Ram. Solid State Drive: New Challenge for Forensic Investigation. 2017: Culminating Projects in Information Assurance. 30.

[9] Ramadhan, Rizdqi Akbar, Prayudi, Yudi and Sugiantoro, Bambang.Implementasi Dan Analisis Forensika Digital Pada Fitur Trim Solid State Drive. 2017, TEKNOMATIKA, 9(2), 1-13.

[10] Rosalina, Vidila, Suhendarsah, Andri and Natsir, M. Analisis Data Recovery Menggunakan Software Forensic: Winhex And X-Ways Forensic. 2016, PROSISKO, 3(1), 51-55.

[11] Faiz, Muhammad Nur, Umar, Rusydi and Yudhana, Anton.Implementasi Live Forensics untuk Perbandingan Browser pada Keamanan Email. 2017, JISKA, 1(3), 108-114. 
[12] Riadi, Imam, Umar, Rusydi and Firdonsyah, Arizona. Identification of Digital Evidence On Android's Blackberry Messenger Using NIST Mobile Forensic Method. 2017, International Journal of Computer Science and Information Security (IJCSIS), 15(5), 155-160.

[13] Anggara Putra, Roni, Fadlil, Abdul and Riadi, Imam.Forensik Mobile Pada Smartwatch Berbasis Android. 2017, JURTI, 1(1), 41-47.
[14] Riadi, Imam, Umar, Rusydi and Sukarno, Wasito.Analisis Forensik Serangan SQL Injection Menggunakan Metode Statis Forensik. Program Pascasarjana Universitas Muhammadiyah Yogyakarta (PPs UMY). Prosiding Interdisciplinary Postgraduate Student Conference 1st. 102-103.

[15] Rafique, Mamoona and Khan, M.N.A.Exploring Static and Live Digital Forensics: Methods, Practices and Tools. 2013, International Journal of Scientific \& Engineering Research, 4(10), 10481056. 